\title{
Comparison of 16S-ITS rDNA RFLP Profiles of Bacillus sp. Isolated from Milk and Different Water Sources
}

\author{
Şakire Hanoğlu ${ }^{1}$, S. Elif Korcan ${ }^{2}$, S. Feyza Erdoğmuş,*, Muhsin Konuk ${ }^{4}$ \\ ${ }^{1,2}$ Biology Department, Faculty of Science and Literature, Afyon Kocatepe University, Afyonkarahisar, Turkey \\ ${ }^{3}$ Department of Laboratory and Veterinary Health, Technical Vocational School of Higher Education of Bayat, Afyon \\ Kocatepe University, Afyonkarahisar, Turkey \\ ${ }^{4}$ Department of Molecular Biology and Genetics, Faculty of Engineering and Natural Sciences, Uskudar University, \\ İstanbul, Turkey, e-posta sfeyza@aku.edu.tr
}

Geliş Tarihi:19.06.2014; Kabul Tarihi:31.07.2014

Keywords

Bacillus sp.;

Extracellular enzyme;

16S-ITS rDNA; RFLP

\begin{abstract}
The aim of this research was the isolation of thermophilic Bacillus sp. from different sources and grouping by 16S-ITS rDNA RFLP. Seventy-four thermophilic strains were isolated from various environmental samples. Since fifteen isolated strains were Gram (+), endospore forming rods, they were identified as Bacillus $\mathrm{sp}$. These strains were screened for the existence of five extracellular enzyme activities. These were, lipases, amylases, proteases, xylanases, cellulases. 16S-ITS rDNA RFLP profiles were produced by using two restriction endonucleases Taq I and Hae III. The isolated strains were clustered into eigth groups by Taq I restriction profiles of 16S-ITS rDNA while seven groups were obtained by Hae III digestion profiles.
\end{abstract}

\section{Farklı Su ve Süt Kaynaklarından İzole Edilen Bacillus sp.'Iarın 16S-ITS rDNA RFLP Profillerinin Karşılaştırılması}

\footnotetext{
Özet

Bu çalışmanın amacı farkı kaynaklardan izole edilen termofilik Bacillus sp.'ları 16S-ITS rDNA RFLP ile

Anahtar kelimeler

Bacillus sp.;

Ekstraselüler enzim;

16S-ITS rDNA; RFLP

gruplandırmaktır. Çeşitli çevresel örneklerden yetmiş dört suş izole edilmiştir. Gram (+), endospor oluşturan, basil şeklindeki izolatlar Bacillus olarak identifiye edilmiştir Bu suşlar; lipaz, amilaz, proteaz, ksilinaz ve selulazdan oluşan ekstraselülar beş enzim aktivitesi açısından incelenmiştir. 16S-ITS rDNA RFLP profilleri Taqı ve Haellı olmak üzere iki farklı restriksiyon enzimi kullanılarak çıkarılmıştır. İzolatlar Taql ile sekiz, HaellI ile yedi farklı restriksiyon grubu oluşturmuştur.
} 


\section{Introduction}

During the last decades, there was an increasing interest in development of different food safety measures to ensure safe and qualitative food products (Nada et al., 2012). Nowadays, there has been considerable increase in interest in thermophilic bacteria of the genus Bacillus, because of their possible contamination of heated food products (Saito, 1973; Rainey et al., 1994; AlAwadhi et al., 1998; Touzel et al., 2000; Tyndall et al., 2002; Paes and O'Donohue, 2006; Tang et al., 2006). Raw milk provides a very suitable medium for bacterial growth, and milk quality is largely dependent on its microflora (González et al., 2013). Bacillus species and their spores, often present in raw milk, play an important role in the dairy industry in being responsible for spoilage of raw and pasteurized milk (González et al., 2013). Therefore, within the dairy processing context, thermophilic bacilli are used as hygiene indicators in processed product. Geobacillus stearothermophilus, Bacillus licheniformis and Bacillus subtilis have been isolated from raw milk and milk products (Ronimus et al., 2003). Consequently, careful microbiological monitoring of milk is required (Nada et al., 2012).

The 16S internal transcribed spacer (16S-ITS) rRNA gene RFLP method has already been used for the identification of bacteria of diverse origin; lactic acid bacteria (Bulut et al., 2005), lactobacilli (Yavuz et al., 2004a), thermophilic bacilli Yavuz et al., 2004b)and alkalophilic bacilli (Akbalik et al., 2004). Some researcher have reported that the $16 \mathrm{~S}-23 \mathrm{~S}$ ribosomal RNA intergenic transcribed spacer (ITS) has much greater variability in sequence than $16 \mathrm{~S}$ rRNA and has been useful for differentiation of closely related bacterial species(Shaver et al., 2001; Ouoba et al., 2004). So far no reports describing the characterization of Bacillus sp. has been isolated from raw milk samples from Turkey have been available in the literature.

The aim of this study was to comparison of 16S-ITS rDNA RFLP profiles of Bacillus sp. isolated from milk and different water sources and determination of the physical growth characteristics demands.

\section{Materials and Methods}

\subsection{Isolation and growth conditions}

All chemicals were of reagent grade and were purchased from Sigma-Aldrich (USA). Five hot spring water, eleven drinking water, two waste water and forty raw milk samples from Afyonkarahisar were taken aseptically. The hot spring water samples were collected into thermos flasks in order to maintain the temperature during transportation. Enrichment method was used for isolation. $10 \mathrm{ml}$ of samples were subjected to heat treatment for $10 \mathrm{~min}$ at $80^{\circ} \mathrm{C}$ in a waterbath in order to eliminate non-spore forming bacteria (Mora et al., 1998). After pasteurization, the samples were transferred into $100 \mathrm{ml}$ of Broth (yeast extract $1 \mathrm{~g} / \mathrm{l}$, glucose $1 \mathrm{~g} / \mathrm{l}$ ). Incubation was performed in a rotary shaker at $60^{\circ} \mathrm{C}$ until a turbidity obtained. Then $500 \mu \mathrm{l}$ of the broth was plated on agar medium (yeast extract $1 \mathrm{~g} / \mathrm{l}$, glucose $1 \mathrm{~g} / \mathrm{l}$, agar agar $15 \mathrm{~g} / \mathrm{l}$ ) and incubated for $48-72 \mathrm{~h}$ at $60^{\circ} \mathrm{C}$. Single colonies with different morphologies were picked.

\subsection{Morphologic, biochemical and physiological characterization}

Gram staining, endospore forming rods, oxidase, catalase, were determined for each isolate 15 isolated strains were determined for each isolate. Bacillus is a rod-shaped, gram positive, spore forming, aerobic or facultatively anaerobic, usually catalase positive, chemoorganotrophic bacterium 
with a fermentative or respiratory mechanism (Holt and Krieg, 1994). Therefore, if an isolate shows general characteristics of Bacillus genus, it is referred as Bacillus sp. Protease screening was performed according to the method described by Priest et al. (1988). For amylase, xylanase and cellulase screening, the mineral medium described by Bragger et al. (1989). Lipase screening was performed according to the method described by Haba et al. (2000). Physiological parameters included growth at different ranges of temperature $\left(37^{\circ} \mathrm{C}\right.$ to $\left.70^{\circ} \mathrm{C}\right)$, sodium chloride concentration ( $1 \%$ to $6 \%$ ) and $\mathrm{pH}$ values (4,5 to 9 ) were determined.

\subsection{Genomic DNA Isolation of Isolates and Amplification of 165 rDNA - ITS Region}

DNA extraction of the bacterial isolates was carried out by using GF-1 Bacterial DNA Extraction Kit (Vivantis). The 16S rDNA - ITS Region from individual bacterial isolates was amplified by the polymerase chain reaction (PCR). PCR amplification was performed using L1 and EGE1 PCR primers. The forward primer was: L1: 5'AGAGTTTGATCCTGGCTCAG-3' and the reverse primer was EGE1: 5'-CAAGGCATCCACCGT-3'(Jensen et al., 1993; Akbalik et al., 2004). The PCR reaction mixtures $(50 \mu \mathrm{l})$ contained, $2 \mu \mathrm{l}$ of genomic DNA template, $5 \mu \mathrm{l}$ 10x reaction bufer, 2,5 $\mu \mathrm{l} 25 \mathrm{mM}$ $\mathrm{MgCl}_{2}, 8 \mu \mathrm{l}$ dNTPs (each of $200 \mu \mathrm{l}$ ), $50 \mathrm{pmol}$ of each of the DNA primers, $0,25 \mu \mathrm{l}$ Taq DNA polymerase. The PCR was carried out in a thermal cycler. The reaction was subjected to 40 cycles of amplification of $16 \mathrm{~S}$ rDNA - ITS gene region (initial cycle of $5 \mathrm{~min}$ at $94{ }^{\circ} \mathrm{C}$, denaturation at $94{ }^{\circ} \mathrm{C}$ for $1 \mathrm{~min}$, annealing at $42{ }^{\circ} \mathrm{C}$ for $1 \mathrm{~min}$, elongation $72{ }^{\circ} \mathrm{C}$ for $1 \mathrm{~min}$ and final extension step at $72^{\circ} \mathrm{C}$ for $10 \mathrm{~min}$ ). Amplified DNA fragments were analyzed on $1 \%(\mathrm{w} / \mathrm{v})$ agarose gels stained with ethidium bromide and photographed with UV illumination.

\subsection{Restriction Fragment Length Polymorphism (RFLP)}

Haelll (GG.CC) and Taql (T.CGA) restriction endonucleases were used for RFLP. Ten $\mu$ of the PCR products were digested with 5 units of each of the enzymes in a final volume of $50 \mu$ l. Ten $\mu$ of each PCR product was transferred into eppendorf tubes and $40 \mu \mathrm{l}$ restriction enzyme mixtures $(5 \mu \mathrm{l}$ restriction enzyme bufer, $35 \mu$ sterile deionized water, $10 \mu \mathrm{LNA}, 0.5 \mu \mathrm{l}(5 \mathrm{U})$ restriction enzyme) were added. Taql digestion samples were overlaid with mineral oil and the restriction reactions were carried out in a water bath at $65{ }^{\circ} \mathrm{C}$. Haelll digestions were performed at $37^{\circ} \mathrm{C}$. Both reactions were incubated overnight. After the digestion, DNA was extracted as described and dissolved in $15 \mu \mathrm{l}$ 1xTE (Yavuz et al., 2004b). For the seperation of restriction fragments $1 \%(\mathrm{w} / \mathrm{v})$ agarose gels were prepared. Electrophoresis was carried out for 20 $\min$ at $145-150 \mathrm{~V}$. At the end oft the electrophoresis, the gel was removed and DNA was visualised on a UV illuminator.

\section{Results}

In this study, $\mathbf{7 4}$ thermophilic microorganisms were isolated from different samples (twenty isolates from hot spring water, eleven isolates from tap water, two isolates from waste water and forty isolates from milk samples) (Table 1). Colony morphologies were determined under the light microscope. Coccus shaped bacteria, gram negative and unpure isolates were eliminated. In total fifteen isolated strains were found to be sporeforming, gram-positive, catalase-positive and rodshaped were selected for further studies. Eighty per cent of the isolates were from raw milk, 13\% from hot water and $7 \%$ were from waste water samples.

Physiological and enzymatic characteristics status of the isolates were shown in Table 1 . All isolates tested were able to grow $35-45^{\circ} \mathrm{C}$ but only R1, R2, 
R34 were able to grow $60{ }^{\circ} \mathrm{C}$. Only milk samples were able to grow $\geq 55^{\circ} \mathrm{C}$. None of them were able to grow $75^{\circ} \mathrm{C}$. However no growth was observed at $75{ }^{\circ} \mathrm{C}$ suggesting that these isolates could be thermophil. The isolates were tested for growth at different $\mathrm{pH}$. All the isolates were able to grow at $\mathrm{pH} \geq 6.5$. Also R1, R34 were able to grow $\mathrm{pH} 4.5$ and 5.0. This result could indicate that isolates were alkalophiles. Growth of the isolates were also observed at $0,3 \%, 1 \%, 3 \%, 6 \% \mathrm{NaCl}$ concentrations on agar plates. Test results showed that all of this isolates except that isolates $\mathrm{W} 12$ and R35 were able to grown $0,3-6 \%$ salt concentrations. The isolates were screened for lipase, amylase, protease, xylanase, cellulase activity. Only isolate W12 was able to produce amylases. None of the enzymes were detected at other isolates (Table 2 ).

Table 1. Samples, isolated from from different sources

\begin{tabular}{|c|c|c|}
\hline Samples & $\begin{array}{l}\text { Number } \\
\text { of isolate }\end{array}$ & Name of the isolate \\
\hline \multicolumn{3}{|l|}{ Hot Water } \\
\hline Aydın thermal & 2 & $\mathrm{H} 1, \mathrm{H} 2$ \\
\hline Kadı thermal & 13 & $\begin{array}{c}\mathrm{H} 3, \mathrm{H} 4, \mathrm{H} 5, \mathrm{H} 6, \mathrm{H} 7, \mathrm{H} 8, \mathrm{H} 9, \\
\mathrm{H} 10, \mathrm{H} 11, \mathrm{H} 12, \mathrm{H} 13, \mathrm{H} 14, \\
\mathrm{H} 15\end{array}$ \\
\hline Hilal thermal & 2 & $\mathrm{H} 16, \mathrm{H} 17$ \\
\hline Gazlıgöl thermal & 1 & $\mathrm{H} 18$ \\
\hline Kızılcahamam & 2 & $\mathrm{H} 19, \mathrm{H} 20$ \\
\hline \multicolumn{3}{|l|}{ Waste water } \\
\hline Tınaztepe & 1 & W1 \\
\hline Bolvadin & 1 & W2 \\
\hline Bolvadin & 2 & W3,W4 \\
\hline Kadınana & 1 & W5 \\
\hline Savran & 1 & W6 \\
\hline Cumhuriyet & 1 & W7 \\
\hline Kocaeli & 2 & W8, W9 \\
\hline Aydın Çine & 1 & W10 \\
\hline
\end{tabular}

\begin{tabular}{|c|c|c|}
\hline Bilecik & 1 & W11 \\
\hline Şuhut & 1 & W12 \\
\hline Antalya & 1 & W13 \\
\hline Isparta Barla & 1 & W14 \\
\hline \multicolumn{3}{|l|}{ Raw Milk } \\
\hline Fetibey & 10 & $\begin{array}{c}\mathrm{R} 1, \mathrm{R} 2, \mathrm{R} 3, \mathrm{R} 4, \mathrm{R} 5, \mathrm{R} 6, \mathrm{R} 7, \\
\mathrm{R} 8, \mathrm{R} 9, \mathrm{R} 10\end{array}$ \\
\hline Erenler & 5 & $\mathrm{R} 11, \mathrm{R} 12, \mathrm{R} 13, \mathrm{R} 14, \mathrm{R} 15$ \\
\hline Gazlıgöl & 1 & R16 \\
\hline Çobanlar & 17 & $\begin{array}{l}R 17, R 18, R 19, R 20, R 21, \\
R 22, R 23, R 24, R 25, R 26, \\
R 27, R 28, R 29, R 30, R 31, \\
R 32, R 33\end{array}$ \\
\hline Sinanpaşa & 5 & R34, R35, R36, R37, R38 \\
\hline
\end{tabular}

Genomic DNA was successfully extracted from fifteen bacterial isolates. Amplification of 16S-ITS region mostly produced one distinct DNA fragment of approximately 2000-2500 bp in length. In order to determination of 16S-ITS rDNA restriction profiles, two restriction enzymes, Taq I and Hae III were used and similar profiles are grouped. 16S-ITS rDNA RFLP profiles of Taq I groups of isolates were shown in Table 3. According to the results of Taq I enzyme digestion, strains were clustered into eigth genotypic groups (T1, T2, T3, T4, T5, T6, T7, T8). While hot spring water isolates $\mathrm{H} 16$ and $\mathrm{H} 17$ were located in T1 group (1035, 500, 328 bp) milk sample isolates were clustered into different genotypic groups (T2 T3, T4, T5, T7, T8). Waste water isolate W12 took part in a separate group in T2 (845, 535, 379, 291 bp). Isolates were divided into seven major groups depending on the results of the digestive restriction enzyme Hae III (HA1, HA2, HA3, HA4, HA5, HA6 and HA7) (Table 4).

$\mathrm{H} 16$ and $\mathrm{H} 17$ isolated from hot spring water were located in HA1 group (514- 383 bp) but waste water isolates W12 was located in HA2 group. Most 
of isolates isolated from milk samples (R1, R2, R3, R11, R12, R13, R16) located HA3 group $(682,514$, 365,327 bp). According to the two enzymes digestion dairy isolates in different groups took part from water-borne isolates.

Table 3. $16 \mathrm{~S}$-ITS rDNA RFLP profiles of Taq I genotypic groups of isolates.

\begin{tabular}{ccc}
\hline $\begin{array}{c}\text { Groups of 16S-ITS } \\
\text { rDNA RFLP profiles }\end{array}$ & Isolate No & $\begin{array}{c}\text { Fragment length } \\
\text { after digestion by } \\
\text { Taq I (bp) }\end{array}$ \\
\hline T1 & H16, H17 & $1035,500,328$ \\
T2 & R37 & 845, 535, 379, 291 \\
T3 & R12, R16 & 568, 474, 412, 182 \\
T4 & R13 & $535,535,389,291$ \\
T5 & W12 & $293,412,318$ \\
T6 & R17, R34 & 535,379 \\
T7 & R35, R36 & $1018,845,461,379$ \\
T8 & & \\
\hline
\end{tabular}

The results of the Table 4 generated from both of the restriction enzyme profiles were combined and ten distinct homology groups of the isolated strains were obtained. Hot spring waters isolates ( $\mathrm{H} 16$ and H17) located in G1 (514- 383 bp). Waste water Isolates W12 was located in G1 group. Milk sample isolates were clustered into eigth different genotypic groups (G1, G2, G3, G4, G5, G6, G7, G8). Analysis of the homology groups indicated that isolates were isolated from different sources could be separated by 16S-ITS rDNA RFLP.
Table 4 16S-ITS rDNA RFLP profiles of Hae III genotypic groups of isolates.

\begin{tabular}{ccc}
\hline $\begin{array}{c}\text { Groups of } \\
\text { 16S-ITS } \\
\text { rDNA RFLP } \\
\text { profiles }\end{array}$ & Isolate No & $\begin{array}{c}\text { Fragment length } \\
\text { after digestion by } \\
\text { Hae III (bp) }\end{array}$ \\
\hline HA1 & H16, H17 & 514,383 \\
HA2 & W12 & 285,188 \\
HA3 & R1, R2, R3, R11, R12, R13, & $682,514,365,327$ \\
HA4 & R16 & 300 \\
HA5 & R37 & \\
HA6 & R36, R19 & $682,527,300$ \\
HA7 & R34 & 682,514 \\
& R35 & 278,175
\end{tabular}


Table 2. Physiological and enzimatic characteristics of rod-shaped, gram positive, spore forming isolates.

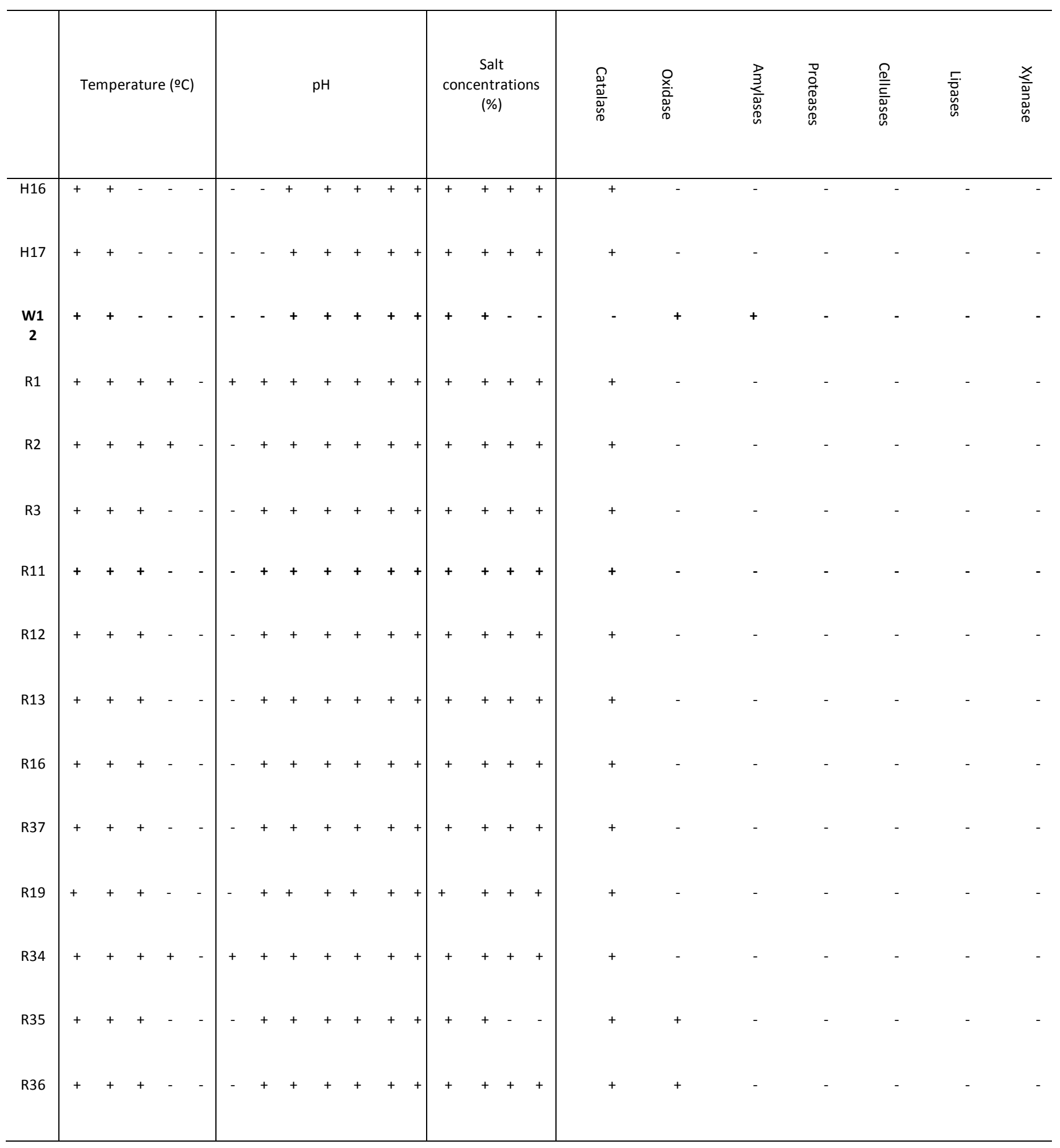




\section{Discussions and Conclusions}

In this study, thermophilic Bacillus sp. from different sources were isolated and grouped by 16S-ITS rDNA RFLP. Seventy four thermophilic microorganisms were isolated from different samples and coccus shaped bacteria, gram negative and unpure isolates were eliminated. Fifteen isolates with different colony morphology were found to be spore-forming, Gram-positive, catalase-positive and rod-shaped were selected for further studies.

Thermophilic Bacillus species, with growth temperature optima between 45 and $70^{\circ} \mathrm{C}$, have been isolated from a wide range of environments (Peng etal., 2003). In the dairy industry, the facultative thermophiles belong to the Bacillus genus and tend to grow at both mesophilic and thermophilic temperatures, depending on the strain. Some examples of species include Bacillus licheniformis, Bacillus coagulans, Bacillus pumilus, Bacillus sporothermodurans and Bacillus subtilis (Burgess et al., 2010). Nielsen et al. (1995) have demonstrated that a strain of $B$. clausii has tolerated $8 \% \mathrm{NaCl}$ whereas other membershave tolerated about $10 \% \mathrm{NaCl}$. Moderate halophiles are capable to grow over a wide range of salt concentrations (optimal growth at 3-15\% $\mathrm{NaCl}$ ) (Joo and Chang, 2005). According to Krulwich (1995) alkalophiles can be divided into two groups; alkaline-tolerants (optimal growth at the $\mathrm{pH}$ range 7.0-9.5) and alkalophilics (optimal growth at the $\mathrm{pH}$ range 10.0 and 12.0$)$.

This result could indicate that isolates were alkaline-tolerants and moderate halophiles. Our results showed that all isolates except W12 and R35 were able to grown $0,3-6 \%$ salt concentrations and at $\mathrm{pH} \geq 6,5$. it is shown that our results, as well as, milk sample isolates were able to grow $\geq 55^{\circ} \mathrm{C}$ (Table 1). Burgess et al. (2010) reported that the presence of thermophiles in dairy products is an indicator of poor hygiene during processing.

We found that only waste water isolate W12 was able to produce amylases. Extracellular enzymes from alkalophilic microorganisms can be active at alkaline $\mathrm{pH}$ (Ghanem etal., 2000) and most of the alkalophilic enzymes show optimal activity alkali pH (Takami and Horikoshi, 2000).

In recent study the 16S-ITS rRNA gene RFLP method has been successfully applied to the species-level identification of thermophilic bacilli (Yavuz et al., 2004b) and alkalophilic bacilli (Akbalik et al. 2004). Consequently, fifteen isolated strains were characterized according to their 16S-ITS rDNA restriction profiles. Yavuz et al. (2004b) reported that seventeen different genotypic groups have been obtained after 16S rDNA-ITS Region RFLP of 112 isolated strains by Taq I and Hae III. On the other hand Bulut et al. (2003) has used the same method for further identification; isolates which could'nt have been identified phenotypically, could have been identified by using $16 \mathrm{~S}$ rRNA-ITS region RFLP. Akbalık et al. (2004) results indicated that 16S-ITS rDNA RFLP could be a rapid method in 
revealing genetic diversity of the large collections of alkalophilic bacteria at species level. They were reported that Both Taql and Haelll were found to be necessary for the discrimination of the strains by this method. Similar to this study, on the identification of thermophilic bacilli from marine thermal vents of Eolian Islands, seventy-four thermophilic isolates have been compared according to their restriction patterns of amplified 16S rDNA with eigth type strains of Bacillus (Caccamo et al., 2001). They have obtained thirteen different $A l u$ I restriction patterns and $\% 78$ of isolates were recognized as representatives of different Bacillus species. In another work Blanc et al. (1997) the Hae III restriction profiles of $16 \mathrm{~S}$ rDNAs have been compared with four different reference strains. Five different groups have been found, four of the them including the reference strains. Kuisine et al. (2002) has evaluated the thermophilic proteolytic isolates from a geothermal site in Lithuania based on 16S rDNARFLP and ITS- PCR analyses. Acording to PCR-RFLP 42 strains have been divided into six distinct groups. Another study indicated that $16 \mathrm{~S}$ rDNA and ITS regions were used separately for RFLP analysis (Caccamo et al., 2001).

In the present study, most isolates showed common into same physiological characteristics and showed common enzyme production On the other hand, some of them differed from each other in terms of genotypic group. Isolates were clustered into different genotypic groups by both Taq I and Hae III. According to the results of Taq I enzyme digestion, alkaline-tolerants and moderate halophiles bacillus strains were clustered into eigth genotypic groups. Those isolates were divided into seven major groups depending on the results of the digestive restriction enzyme Hae III. The results of the Table 4 generated from both of the restriction enzyme profiles were combined and 10 distinct homology groups of the isolates. According to the two enzymes digestion dairy isolates in different groups took part from water-borne isolates. Analysis of the homology groups indicated that isolates were isolated from different sources could be separated by 16S-ITS rDNA RFLP and This metot is suitable for distinguishing among Bacillus sp. where were isolated.

\section{Acknowledgements}

We are indebted to Afyon Kocatepe University (Project no. 11. FEN. BíL.13) for its financial support.

\section{References}

Akbalik, G., Gunes, H., Yavuz, E., Yasa, I., Harsa, S., Elmaci, Z.S. and Yenidunya, A.F., 2004. Identification of extracellular enzyme producing alkalophilic bacilli from Izmir province by 16S-ITS rDNA RFLP. Journal of Applied Microbiology, 97, 766-773.

Al-Awadhi, S., Welch, S.G., Smith, K.E. and Williams, R.A.D., 1998. BstB7SI (R CCGGY), a thermostable isoschizomer of Cfr10I, from a strain of Bacillus stearothermophilus isolated from oil-contaminated soil in Kuwait. FEMS Microbiology Letters, 160, 205-208.

Blanc, M., Marilley, L., Beffa, T. and Aragno, M., 1997. Rapid identification of heterotrophic, thermophilic, spore-forming bacteria 
isolated from hot composts. International Journal of Systematic Bacteriology, 47, 12461248.

Bragger, J.M., Daniel, R.M., Coolbear, T. and Morgan, H.W., 1989. Very stable enzymes from extremely thermophilic archaebacteria and eubacteria. Applied Microbiology and Biotechnology, 31, 556-561.

Bulut, C., Gunes, H., Okuklu, B., Harsa, S., Kilic, S., Coban, H.S. and Yenidunya, A.F., 2005. Homofermentative lactic acid bacteria of a traditional cheese, Comlek peyniri from Cappadocia region. Journal of Dairy Research, 72, 19-24.

Burgess, S.A., Denise, L. and Steve, H., 2010. Flint thermophilic bacilli and their importance in dairy processing. International Journal of Food Microbiology, 144, 215-225.

Caccamo, D., Maugeri, T.T. and Gugliandolo, C., 2001. Identification of thermophilic and marine bacilli from shallow thermal vents by restriction analysis of their amplified 16S rDNA. Journal of Applied Microbiology, 91, 520-524.

Ghanem, E.H., Al-Sayed, H.A. and Saleh, K.M., 2000. An alkalophilic thermostable lipase produced by a new isolate of Bacillus alcalophilus. World Journal of Microbiology and Biotechnology, 16, 459-464.

González, M.J., Gorgoroso, F., Reginensi, S.M., Olivera, J.A. and Bermúdez, J., 2013. Polyphasic identification of closely related Bacillus subtilis and Bacillus amyloliquefaciens isolated from dairy farms and milk powder. Journal of Microbiology and Biotechnology Food Science, 2(5), 23262331.

Haba, E., Bresco, O., Ferrer, C., Marques, A., Basquets, M. and Manresa, A., 2000. Isolation of lipase secreting bacteria by deploying used frying oil as selective substrate. Enzyme and Microbial Technology, 26, 40-44.

Holt, J.G. and Krieg, N.R., 1994. Enrichment and Isolation. In: Gerhardt P (ed) Methods for general and molecular bacteriology, ASM Publications, 197-200.

Jensen, M.A., Webster, J.A. and Strauss, N., 1993. Rapid identification of bacteria on the basis of polymerase chain reaction-amplified ribosomal DNA spacer polymorphisms. Applied and Environmental Microbiology, 59, 943-952.

Joo, H.S. and Chang, C.S., 2005. Oxidant and SDSstable alkaline protease from a halotolerant Bacillus clausii 1-52: enhanced production and simple purification. Journal of Applied Microbiology, 98, 491-497.

Krulwich, T.A., 1995. Alkaliphiles: 'basic' molecular problems of $\mathrm{pH}$ tolerance and bioenergetics. Molecular Microbiology, 15, 403-410.

Kuisiene, N., 2002. Jomantiene R, Valiunas D, Chitavichius D Characterization of thermophilic proteolytic spore-forming bacteria from a geothermal site in Lithuania based on $16 \mathrm{~S}$ rDNA RFLP and ITS-PCR analyses. Microbiology, 71, 824-828.

Mora, D., Fortina, M.G., Nicastro, G., Parini, C. and Manachini, P.L., 1998. Genotypic characterization of thermophilic bacilli: a study on new soil isolates and several reference strains. Research in Microbiology, 149, 711-722.

Nada, S., Ilija, D., Igor, T., Jelena, M. and Ruzica, G., 2012. Implication of food safety measures on microbiological quality of raw and pasteurized milk. Food Control, 25, 728-731.

Nielsen, P., Fritze, D. and Priest, F.G., 1995. Phenetic diversity strains:proposal for nine 
new species of alkaliphilic Bacillus species. Microbiology, 141, 1745-1761.

Ouoba, L.I.I., Diawara, B., Amoa-Awua, W., Traore, A.S. and Moller, P.L., 2004. Genotyping of starter cultures of Bacillus subtilis and Bacillus pumilus for fermentation of African locust bean (Parkia biglobosa) to produce Soumbala. International Journal of Food Microbiology, 90, 197- 205.

Paes, G. and O'Donohue, M.J., 2006. Engineering increased thermostability in the thermostable $\mathrm{GH} \quad 11$ xylanase from Thermobacillus xylanilyticus. Journal of Biotechnology, 125, 338-350.

Peng, X., Norihiko, M. and Shigeaki, H., 2003. Isolation and characterization of thermophilic bacilli degrading cinnamic, 4coumaric, and ferulic acids. Applied and Environmental Microbiology, 69, 1417-1427.

Priest, G.F., Goodfellow, M. and Todd, C., 1988. A Numerical classification of the genus Bacillus. Journal of General Microbiology, 134, 1847-1882.

Rainey, F.A., Fritze, D. and Stackebrandt, E., 1994. The phylogenetic diversity of thermophilic members of the genus Bacillus as revealed by $16 \mathrm{~S}$ rDNA analysis. FEMS Microbiology Letters, 115, 205-212.

Ronimus, R.S., Parker, L.E., Turner, N., Poudel, S., Ruckert, A. and Morgan, H.W., 2003. RAPDbased comparison of thermophilic bacilli from milk powders. International Journal of Food Microbiology, 85, 45-61.

Saito, N., 1973. A thermophilic extracellular $\alpha-$ amylase from Bacillus licheniformis. Archieves of Biochemistry and Biophys, 155, 290-298.
Shaver, Y.J., Nagpal, M.L., Fox, K.F., Rudner, R. and Fox, A., 2001. Variation in 16S-23S rRNA intergenic spacer regions among Bacillus subtilis 168 isolates. Molecular Microbiology, 42, 101-109.

Takami, H. and Horikoshi, K., 2000. Analysis of an alkalophilic Bacillus strain from an industrial point of view. Extremophiles, 4, 99-108.

Tang, S.Y., Le, Q.T., Shim, J.H., Yang, S.J., Auh, J.H., Park, C. and Park, K.H., 2006. Enhancing thermostability of maltogenic amylase from Bacillus thermoalkalophilus ET2 by DNA shuffling. FEBS Journal, 273, 3335-3345.

Touzel, J.P., Donohue, M., Debeire, P., Samain, E. and Breton, C., 2000. Thermobacillus xylanilyticus gen. nov., sp. nov., a new aerobic thermophilic xylan-degrading bacterium isolated from farm soil. International Journal of Systematic Bacteriology, 50, 315-320.

Tyndall, J.D., Sinchaikul, S., Fothergill-Gilmore, L.A., Taylor, P. and Walkinshaw, M.D., 2002. Crystal structure of a thermostable lipase from Bacillus stearothermophilus P1. Journal of Molecular Biology, 323, 859-869.

Yavuz, E., Gunes, H., Bulut, C., Harsa, S. and Yenidunya, A.F., 2004. RFLP of $16 S$ rDNA-ITS region to differentiate lactobacilli at species level. World Journal of Microbiology and Biotechnology, 20, 535-537.

Yavuz, E., Gunes, H., Harsa, S. and Yenidunya, A.F., 2004b. Identification of extracellular enzyme producing thermophilic bacilli from Balcova (Agamemnon) geothermal site by 16S-ITS rDNA RFLP. Journal of Applied Microbiology, 97, 810-817. 